\title{
KARAKTERISTIK POKEA (Batissa violacea celebensis Martens 1897) ASAP DENGAN BAHAN PENGASAP YANG BERBEDA
}

\author{
Ardiansyah *, Andi Besse Patadjai, Kobajashi T. Ishamu \\ Jurusan Teknologi Hasil Perikanan Fakultas Perikanan dan Ilmu Kelautan Universitas Halu Oleo, \\ Jalan H.E.A Mokodompit Kampus Bumi Tridharma Anduonohu, Kendari 93232 Sulawesi Tenggara \\ Telepon +6285342693544 \\ *Korespondensi: :ardiansyah0794@gmail.com \\ Diterima: 29 Januari 2019/Disetujui: 23 April 2019
}

Cara sitasi: Ardiansyah, Patadjai AB, Ishamu KT. 2019. Karakteristik pokea (Batissa violacea celebensis Martens 1897) asap dengan bahan pengasap yang berbeda. Jurnal Fish Protech. 2(1):119-129.

\begin{abstract}
Abstrak
Tujuan penelitian ini adalah untuk mengetahui perbedaan bahan pengasap yang berbeda terhadap uji sensorik, proksimat, Polycylic Aromatic Hydrocarbon (PAH) pada pokea asap.Penelitian ini menggunakan rancangan deskriptif yang terdiri dari Pokea asap dengan menggunakan bahan pengasap tempurung kelapa (A1), cangkang kelapa sawit (A2), tempurung kelapa dan cangkang kelapa sawit (A3). uji sensorik pada penelitian ini menunjukkan hasil pada pokea asap nilai aroma tertinggi yaitu 6,6 (A1), Warna tertinggi yaitu 7,3 (A1), Umami tertinggi yaitu 5,9 (A2), Saltiness tertinggi yaitu 5,6 (A1), Tekstur tertinggi yaitu 5,2 (A1) dan (A2). Berdasarkan kandungan proksimat, kandungan kadar protein hasil tertinggi pada pokea asap dengan bahan pengasap cangkang kelapa sawit. Kandungan Polycyclic Aromatic Hidrocarbon kandungan (benzo(a phyrene) hasil terendah pada pokea asap dengan bahan pengasap tempurung kelapa.
\end{abstract}

Kata kunci: Pengasapan, Batissa violacea, tempurung kelapa, cangkang kelapa sawit

\section{CHARACTERISTICS OF POKEA CLAM (Batissa violacea celebensis Martens 1897) SMOKED USING DIFFERENT SMOKE RESOURCES}

\begin{abstract}
The purpose of this study was to evaluated the sensory quality, proximate content and Polycylic Aromatic Hydrocarbon (PAH)profile onsmoked pokea.This study used a descriptive design consisting of Pokea smoke using coconut shell smoked (A1), oil palm shells (A2), coconut shells and palm shells (A3). Sensory test in this study showed that the highest pokea value of smoke was 6.6 (A1), the highest color was 7.3 (A1), the highest color was 5.9 (A2), the highest saltiness was 5.6 (A1), The highest texture is 5.2 (A1) and (A2). Based on the proximate content, the highest content of protein content in pokea smoke using oil palm shell as smoke source. The content of Polycyclic Aromatic Hydrocarbon content (Benzo(a)phyrene)is the lowest result in smoke pokea with coconut shell smoked.
\end{abstract}

Key words: Smoking, Batissa violacea, coconut shell, palm oil shell 


\section{PENDAHULUAN}

Sulawesi Tenggara mempunyai potensi keanekaragaman hayati perairan yang cukup tinggi dan mempunyai potensi cukup besar sebagai sumber daya perikanan.Pokea (Batissa Violacea Celebensis Martens 1897) ini memiliki arti penting pada ekologi dan ekonomi bagi masyarakat yang berada dikawasan sungai Pohara Kabupaten Konawe, Sulawesi Tenggara. Pokea dapat menjaga keseimbangan ekosistem di lingkungannya diantaranya sebagai konsumen yang memfilter organismeorganisme berukuran lebih kecil, komponen tersuspensi dalam air (filter feeder)dan sebagai bioindikator. Selain itu cangkangnya dapat dibuat menjadi perhiasan rumah tangga dan bahan bangunan. Kerang ini diduga endemik karena hanya ditemukan di Sungai Pohara Kabupaten Konawe Sulawesi Tenggara sekitar $25 \mathrm{~km}$ kearah muara pada kedalaman 1-9 meter. Kerang pokea ini telah menjadi salah satu mata pencaharian bagi masyarakat dikawasan sungai Pohara dan bernilai ekonomis, masyarakat menjuluki kawasan mereka dengan sebutan Pohara, pokea harapan rakyat. Masyarakat sekitar memperdagangkan pokea dalam bentuk segar utuh, terlepas dari cangkangnya dan sate.Organisme ini memiliki kandungan gizi yang tinggi terutama pada kandungan protein sehingga baik dikonsumsi, khususnya bagi penderita penyakit liver(Bahtiar, 2005).

Seiring dengan berkembangnya ilmu pengetahuan dan teknologi maka pengolahan hasil perikanan juga semakin berkembang pesat dan terus adanya persaingan di dunia pemasaran, tetapi tetap saja pada proses pengolahan yang ada, harus disesuaikan dengan keinginan dan selera konsumen. (Erdiansyah, 1982) menyatakan bahwa dalam proses pengolahan hasil perikanan tentu akan mengalami beberapa perubahan pada sifat fisik dan kimiawinya yang pada akhirnya akan mempengaruhi padapenilaian sensorik, dimana kualitas produk olahan ikan tersebut sangat menentukan apakah disukai atau tidak oleh konsumen. Salah satu produk olahan yang dilakukan adalah pokea asap.

Pengasapan merupakan salah satu cara untuk pengawetan agar tidak terjadi pembusukan dan menjaga nilai gizinya. Pengasapan juga berfungsi untuk menambah citarasa dan warna pada makanan serta bertindak sebagai antibakteri dan antioksidan (Adawiyah. $R$, 2008) pengawetan tersebut dapat berpengaruh baik oleh mutu maupun daya awet produk yang diasap. Selain itu, cara pengawetan ini pun dapat mempengaruhi mutu dan daya awet mulai dari cara persiapan bahan, jenis asap yang digunakan, kelembaban, kecepatan pengasapan dan suhu pengasapan (Saleh dan Sari, 2007). Bahan pengasap yang digunakan dalam penelitian ini yaitu cangkang kelapa sawit dan tempurung kelapa. Menurut Afrianto dan Liviawati, (1989), zat-zat kimia yang dihasilkan dari pembakaran bahan bakar dalam proses pengasapan dapat memberikan warna kuning keemasan dan dapat memberikan daya tarik pada konsumen. Lebih lanjut dikatakan (Moeljanto, 1992)warna yang dikehendaki oleh konsumen sebagai warna ideal dari hasil proses pengasapan adalah warna kuning emas kecoklatan. Suhu tinggi selama pengasapan juga bersifat anti bakteri. Hal ini yang mempengaruhi jumlah pertumbuhan bakteri dalam proses pengasapan. Pengasapan juga dapat melindungi kerusakan zat gizi secara langsung dan kerusakan mikrobiologis karena asap bersifat bakterisidal (Tejasari, 2005). 
Berdasarkan latar belakang diatas maka diperlukan penelitian untuk menganalisis kualitas kerang pokea yang diasapi menggunakan bahan pengasap yang berbeda.

\section{BAHAN DAN METODE}

\section{Bahan dan Alat}

Bahan yang akan digunakan terdiri atas bahan utama dan bahan pendukung. Bahan utama adalah daging kerang pokea segar. Bahan pendukung adalah tempurung kelapa, cangkang kelapa sawit, untuk bahan pengasap dan garam untuk cita rasa produk.Bahan kimia untuk analisis proksimat adalah aquades, reagen biuret, larutan standar protein, alkohol $80 \%$, petroleum eter, heksan, $\mathrm{NaOH}$ dan kertas saring.

Peralatan yang digunakan dalam penelitian ini ada 2 macam yaitu alat untuk pengolahan dan alat untuk analisis. Alat pengolahan meliputi: alat pengasapan lemari asap sebagai alat pengasapan, baskom untuk menempati pokea segar, pisau untuk memisahkan cangkang pokea, thermometer untuk mengetahui suhu pengasapan, stopwatch untuk mengetahui waktu pengasapan. Alat untuk analisis proksimat meliputi seperangkat alat ekstraksi soxlet, gelas piala, gelas ukur, batang pengaduk, pipet tetes, mikro pipet, corong, tabung reaksi, labu takar, erlenmeyer, desikator, sentrifus, timbangan analitik, gegep, cawan porselin, botol semprot dan spektofotometer $U V$-Vis.

\section{Persiapan Bahan Baku}

Penelitian ini adalah daging pokea segar sebanyak $3 \mathrm{~kg}$ dengan ukuran panjang rata-rata $3,7 \mathrm{~cm}$ dan lebar $3 \mathrm{~cm}$, yang diperoleh dari pedagang pokea diKecamatan Pohara, bahan pengasap tempurung kelapa sebanyak $3 \mathrm{~kg}$ diambil disalah satu kebun kelapa milik masyarakat Pohara, sedangkan cangkang kelapa sawit sebanyak $3 \mathrm{~kg}$ diambil disalah satu pabrik kelapa sawit yang berada di Kecamatan Langgikima Kabupaten Konawe Utara Sulawesi Tenggara dan proses pengasapan dilakukan di Laboratorium Perikanan dan Ilmu Kelautan Universitas Halu Oleo.

\section{Prosedur Penelitian}

Pokea asap dengan metode pengasapan tradisional adalah pokea dicuci bersih untuk menghilangkan pasir dan kotoran lainnya,pokea yang telah dicuci ditampung didalam keranjang plastik dan dibiarkan beberapa saat untukpenirisan air cucian. Kemudian pokea ditimbang dan di lakukan perebusan, pokea direbus diatas panci selama 20 menit dan ditambahkan air sebanyak 4 liter dan dilarutkan garam sebanyak 100 gr. Kemudian setelah selesai direbus lalu diadakan pemisahan daging pokea dan cangkangnya, setelah itu pokea ditimbang sebanyak 600 gr dan dibagi menjadi 3 bagian.Setelah dibagi menjadi tiga bagian, lalu dilakukan pengasapan selama \pm 30 menit dengan suhu $70{ }^{\circ} \mathrm{C}$, dengan perlakuan tempurung kelapa (A1), cangkang kelapa sawit (A2), cangkang kelapa sawit dan tempurung kelapa (A3) kemudian dilakukan pendinginan.

\section{Parameter Uji}

Uji sensorik ini bermaksud untuk mengetahui tingkat penerimaan panelis terhadap kualitas sensorik produk pokea asap. Penilaian sensorik meliputi aroma (aroma khas pokea asap), warna, umami, asin, tekstur.

Uji sensorik dilakukan dengan mengisi lembar respon panelis. Lembar isian respon panelis diisi oleh panelis yang berjumlah sebanyak 20 orang yang telah melewati tahap training panelis, 
sehingga panelis yang digunakan dalam penelitian ini adalah panelis semi terlatih, panelis memberikan skor sesuai tanggapan panelis terhadap produk pokea asap.

Pengamatan pada penelitian ini yaitu analisis uji proksimat meliputi kadar air (metode gravimetri), kadar protein (metode kjeldhal), kadar abu (metode gravimetri), kadar lemak (metode soxhlet) dan serat kasar (metode gravimetri) Polycyclic aromatic hydrocarbon (PAH) (metode kromatografi gas/GC Lppt, UGM)

\section{Rancangan Penelitian}

Penelitian ini menggunakan Rancangan Deskriptif mutlak dianalisa dengan menggunakan uji kruskal willis,karakterisasi pokea (Batissa violacea var. celebensis Martens1897) asap dengan bahan pengasap yang berbeda. Penelitian ini terdapat 3 perlakuan yaitu Pokea asap dengan menggunakan bahan pengasap tempurung kelapa (A1),Pokea asap dengan menggunakan bahan pengasap cangkang kelapa sawit (A2) dan Pokea asap dengan menggunakan bahan pengasap tempurung kelapa dan cangkang kelapa sawit(A3).

\section{Analisis Data}

Analisis data sensorik dalam penelitian ini menggunakan krusskal wallis dan mann whitney untuk menilai analytical test panelis terhadap sensorik dari pokea asap yangmeliputi aroma (aroma khas pokea),warna,umami, asin, tekstur. Analisis proksimat dalam penelitian ini menggunakan data yang didapatkan dihitung berat keringnya dengan taraf kepercayaan 95\% $(\alpha=$ 0.05) dan PAH (Polysiclic Aromatic Hydrocarbon). Datadijelaskan secara deskriptif.

\section{HASIL DAN PEMBAHASAN}

\section{Uji Sensorik}

Nilai rata-rata atribut sensorik pokea asap dengan perlakuan A1 (tempurung kelapa), A2 (cangkang kelapa sawit) dan A3(tempurung kelapa dan cangkang kelapa sawit) dapat dilihat pada Tabel 1 .

Tabel 1. Nilai rata-rata atribut sensorik pokea asap

\begin{tabular}{ccccc}
\hline \multirow{3}{*}{ No } & \multicolumn{4}{c}{$\begin{array}{c}\text { Bahan Pengasap } \\
\text { PPM }\end{array}$} \\
\cline { 3 - 5 } & Atribut sensorik & A1 & A2 & A3 \\
\cline { 3 - 5 } & & Tempurung & Cangkang & kelapiTempurung kelapa dan \\
& & 6,6 & 4,8 & cangkang kelapa sawit \\
\hline Aroma & 7,3 & 3,8 & 5,6 \\
Warna & 5,6 & 5,9 & 4,4 \\
Umami & 5,6 & 4,4 & 5,1 \\
Saltiness & 5,2 & 5,2 & 4,0 \\
Tekstur & 5 sawit & 5,1 \\
\hline
\end{tabular}

Uji sensorik bertujuan untuk mengetahui respon panelis untuk memberikan penilaian terhadap produk pokea asap. Analytical test terhadap suatu produk dipengaruhi oleh warna, aroma, tekstur dan rasa (Laksmi, 2012).
Pokea asap memiliki alat ukur yang telah diamati meliputi penilaian aroma (aroma khas pokea asap), warna, umami, saltiness, tekstur, yang disajikan pada tabel 1 Hasil penelitian menunjukkan bahwa perbedaan bahan 
baku pokea asap memberikan dampak yang berbeda-beda terhadap penilaian sensorik.

\section{Aroma}

Hasil uji sensorik terhadap aroma pokea asap dengan menggunakan bahan pengasap yang berbeda dapat dilihat pada tabel 1. Berdasarkan tabel 1 tersebut dapat dilihat bahwa nilai ratarata aroma tertinggi pada perlakuan tempurung kelapa (A1) 6,6 dan nilai terendah pada perlakuan cangkang kelapa sawit (A2) yaitu 4,8. Hasil panelis pada saat dibanding bau aroma asap pada pokea asap yang dihasilkan dengan bahan pengasap yang berbeda pada perlakuan tempurung kelapa (A1) sangat kuat tercium aroma asap yang di hasilkan. Menurut Adawyah (2007), Ikan yang barumengalami proses pengasapan memiliki aroma asap yang lembut sampai cukuptajam atau tajam, tidak tengik, tanpa bau busuk, tanpa bau asing, tanpa bau apekdan asam.

Aroma yang dihasilkan pada pokea asap dengan menggunakan bahan pengasap yang berbeda, sangat bervariasi. Aroma asap yang dihasilkan pokea asap dengan bahan pengasap tempurung kelapa (A1) sangat tajam sedangkan pada pokea asap dengan bahan pengasap cangkang kelapa sawit (A2) aroma asap yang dihasilkan sangat harum. Menurut Isamuet al (2012) yang meneliti penilaian sensorik pada aroma ikan cakalang asap berbagai produsen yang terdapat di Kendari, yaitu bernilai

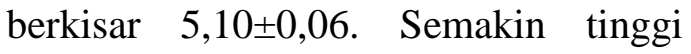
konsentrasi asap yang diberikan maka aroma dan rasa asap pada ikan pun akan semakin meningkat dan ikan yang baru mengalami proses pengasapan memiliki aroma asap yang lembut sampai cukup tajam atau tajam, tidak tengik, tanpa bau busuk, tanpa bau asing, tanpa bau apek dan asam (Martinez et al., 2007).

\section{Warna}

Hasil yang diperoleh menunjukkan bahwa analytical test panelis terhadap warna memiliki nilai rata-rata tertinggi pada perlakuan tempurung kelapa (A1) 7,3 dan nilai terendah pada perlakuan cangkang kelapa sawit (A2) yaitu 3,8 dan perlakuan tempurung kelapa dan cangkang kelapa sawit (A3) 4,4. Warna yang dihasilkan pada pokea asap dengan perlakuan tempurung kelapa (A1) lebih dominan, karena warna yang dihasilkan lebih kecolatan dibanding perlakuan lain. Menurut Afrianto dan Liviawati, (1989), zat-zat kimia yang dihasilkan dari pembakaran bahan bakar dalam proses pengasapan dapat memberikan warna kuning keemasan dan dapat memberikan daya tarik pada konsumen. Menurut Isamuet al (2012) yang meneliti penilaian sensorik pada warna ikan cakalang asap berbagai produsen yang terdapat di Kendari, yaitu nilai berkisar 4.91 \pm 0.30 . Menurut Giullen dan Manzanos, (2002), melaporkan bahwa asap dapat berperan sebagai pemberi warna pada tubuh ikan sehingga ikan yang diawetkan dengan proses pengasapan berwarna kuning keemasan dan dapat membangkitkan selera konsumen untuk menikmatinya. Semakin tinggi konsentrasi asap yang diberikan maka warna ikanpun akan semakin gelap atau kecokelatan.

\section{Umami}

Hasil yang diperoleh menunjukkan bahwa analytical test panelis terhadap umami memiliki nilai rata-rata tertinggi pada perlakuan cangkang kelapa sawit (A2) 5,9 dan nilai terendah pada perlakuan tempurung kelapa dan cangkang kelapa sawit (A3) 5,1 dan perlakuan cangkang kelapa sawit (A2) 5,9. Umami merupakan yang sangat penting dalam menentukan keputusan konsumen untuk 
menerima atau menolak suatu produk makanan. Rasa umami disebut sebagai rasa dasar kelima disamping rasa manis, asin, asam dan pahit. Agar suatu senyawa dapat dikenali rasanya, senyawa tersebut harus larut dalam air liur sehingga dapat mengadakan hubungan mikrovillus dan impuls yang terbentuk dikirim melalui pusat syaraf (Winarno, 2002).

\section{Saltiness (Asin)}

Hasil yang diperoleh menunjukkan bahwa tingkatanalytical test panelis terhadap saltiness memiliki nilai rata-rata tertinggi pada perlakuan tempurung kelapa (A1) 5,6 dan nilai terendah pada perlakuan cangkang kelapa sawit (A2) yaitu 4,4 dan perlakuan tempurung kelapa dan cangkang kelapa sawit (A3) 4,0.Penelitian ini menunjukkan bahwa perbedaan bahan pengasap memberikan saltiness yang berbeda pada pokea asap. penggunaan tempurung kelapa sebagai bahan pengasap memberikan rasa asin yang tinggi pada pokea asap yang dibuktikan dengan analytical test dengan nilai saltiness yang tinggi yakni 5,6.Menurut (Buckle, 1985) juga berpendapat bahwa garam merupakan bahan kimia yang umum digunakan sebagai pengawet dan penambah cita rasa.

\section{Tekstur}

Hasil yang diperoleh menunjukkan bahwaanalytical test panelis terhadap tekstur memiliki nilai rata-rata tertinggi pada perlakuan tempurung kelapa (A1) dan cangkang kelapa sawit (A2) 5,2 dan nilai terendah pada perlakuan tempurung kelapa dan cangkang kelapa sawit (A3) 5,1.Penggunaan tempurung kelapa sebagai bahan pengasap memberikan nilai yang paling tinggi sementara penggunaan cangkang kelapa memberikan nilai tekstur yang paling rendah, dimana pada penelitian ini semakin tinggi nilai tekstur semakin alot daging pokea asap dan semakin rendah nilai tekstur semakin lembut daging pokea asap.Menurut (Isamuet al,2012), perbedaan nilai tekstur ikan asap diduga karena perbedaan kadar air, dimana semakin tinggi kadar air ikan asap, maka nilai teksturnya menjadi rendah, begitupun sebaliknya.Menurut Isamu et al (2012) yang meneliti penilaian sensorik pada tekstur ikan cakalang asap berbagai produsen yang terdapat di Kendari, yaitu nilai berkisar 4,82 $\pm 0,28$.Simko, (2005), melaporkan bahwa selama pengasapan berlangsung terjadi fluktuasi suhu yang tinggi, sehingga menyebabkan kadar airnya berkurang dan menghasilkan tekstur menjadi lebih keras.

Tabel 2. Hasil analisis proksimat pokea asap berdasarkan berat kering

\begin{tabular}{lllll}
\hline \multirow{2}{*}{ No } & \multirow{2}{*}{ Parameter } & Perlakuan & & \\
\cline { 3 - 5 } & & A1 $(\%)$ & A2 $(\%)$ & A3 $(\%)$ \\
\hline 1 & Kadar Air & 14,34 & 18,35 & 19,22 \\
2 & Kadar Abu & 12,02 & 10,87 & 10,99 \\
3 & Kadar Lemak & 18,91 & 24,54 & 23,82 \\
4 & Kadar Protein & 36,52 & 38,13 & 27,07 \\
5 & Serat Kasar & 3,21 & 7,34 & 2,60 \\
6 & BETN & 15,0 & 0,77 & 16,3 \\
\hline
\end{tabular}

Keterangan : A1 $=$ Tempurung kelapa, $\mathrm{A} 2=$ cangkang kelapa sawit, $\mathrm{A} 3=$ tempurung kelapa dan cangkang kelapa sawit 


\section{Uji proksimat}

\section{Kadar Air}

Hasil penelitian kadar air berdasarkan berat kering pada bahan pengasap tempurung kelapa (A1) 14,34; cangkang kelapa sawit (A2) 18,35; tempurung kelapa dan cangkang kelapa sawit (A3)19,22. Rendahnya kadar air berhubungan dengan metode pengasapan yang digunakan yakni pengasapan tradisional dengan bahan pengasap yang berbeda yaitu cangkang kelapa sawit dan tempurung kelapa. Harikedua, (2002) menyatakan bahwa semakin lama waktu pengasapan yang dilakukan maka akan semakin rendah kandungan air dalam produk tersebut. Menurut Isamu et al. (2012) yang meneliti kandungan proksimat pada kadar air ikan cakalang asap berbagai produsen yang terdapat di Kendari,yaitu nilai berkisar 64,13 $\pm 0,50$. Menurut Wibowo (2000), dijelaskan bahwa pada bahan pangan yang dipanaskan, total air/cairan yang keluar dari produk, akan semakin meningkat, dengan semakin meningkatnya temperatur dan lama proses pengasapan. Peningkatan kehilangan cairan akan semakin besar pada suhu pemanasan di atas $100{ }^{\circ} \mathrm{C}$ dan peningkatan waktu lebih dari 45 menit. Semakin tinggi waktu pengasapan maka suatu kadar air yang terkandung dalam daging ikan semakin berkurang dan daging ikan semakin keras. Kadar air merupakan parameter yang penting untuk menentukan kualitas ikan asap yang dihasilkan. Kadar air yang terkandung didalam ikan asap dapat mempengaruhi daya simpan ikan asap. Karena kadar air merupakan media mikroba untuk berkembang biak (Agus et al., 2014).

\section{Kadar Abu}

Hasil kadar abu pada pokea asap berdasarkan berat kering dengan bahan pengasap yang berbeda berkisar 10,87\% sampai $12,02 \%$. Berdasarkan tabel 1.5dapat dilihat bahwa kadar abu tertinggi ditemukan pada pokea asap dengan bahan pengasap tempurung kelapa (A1) yaitu 12,02\% dan kadar abu yang terendah didapatkan pada pokea asap dengan bahan pengasap cangkang kelapa sawit (A2) 10,87\%. Adapun pokea asap dengan bahan pengasap cangkang kelapa sawit dan tempurung kelapa (A3) memiliki kadar abu sebesar 10,99\%. Menurut Isamu et al. 2012) peningkatan kadar abu, disebabkan karena hilangnya kelembaban. Menurut Isamu et al (2012) yang meneliti kandungan proksimat pada kadar abu ikan cakalang asap berbagai produsen yang terdapat di Kendari, yaitu nilai berkisar1,56 $\pm 0,02$. Mardiana et al. (2014) bahwa persentase kadar abu berkorelasi positif terhadap lamanya pengsapan. Menurut Sudarmadji et al. (2003), bahwa kadar abu berhubungan dengan mineral suatu bahan. Mineral yang terdapat dalam bahan dapat merupakan dua macam garam yaitu garam organik dan anorganik. Komponen mineral dalam bahan dapat ditentukan jumlahnya dengan cara menentukan sisa-sisa pembakaran garam mineral tersebut, yang dikenal dengan pengabuan.

\section{Kadar Lemak}

Hasil uji lemak pada pokea asap berdasarkan berat kering dari bahan pengasap yang berbeda berkisar $18,91 \%$ sampai $24,54 \%$ berdasarkan tabel 2 , menunjukkan bahwa hasil analisa lemak yang tertinggi didapatkan pada pokea asap dengan bahan pengasap cangkang kelapa sawit (A2) yaitu $24,54 \%$ dan kadar yang paling rendah analisa lemak yaitu didapatkan pada pokea asap dengan bahan pengasap tempurung kelapa (A1) sekitar 18,91.Pada perlakuan pokea asap dengan bahan 
pengasap cangkang kelapa sawit dan tempurung kelapa (A3) didapatkan kadar lemaksebesar 23,82.Tingginya lemak pada pokea asap dengan bahan pengasap cangkang kelapa sawit diduga karena kandungan yang terdapat pada cangkang kelapa sawit. Menurut Isamu et al (2012) yang meneliti kandungan proksimat pada kadar lemak ikan cakalang asap berbagai produsen yang terdapat di Kendari, yaitu nilai berkisar1.75 \pm 0.59 . Pernyataan ini sesuai dengan Rampon (2002) menyatakan bahwa apabila kadar air ikan menurun maka kadar lemak akan mengalami peningkatan dan sebaliknya.Lemak pokea mengandung asam lemak tak jenuh omega-3 EPA dan DHA yang baik untu tubuh manusia.Lemak makanan merupakan bagian terpenting dalam nutrisi yaitu menambah kalori dan asam lemak penting, bertindak sebagai pembawa vitamin dan meningkatkan flavor makanan (Rahayu,2012)

\section{Kadar Protein}

Hasil kadar protein yang tertinggi didapatkan pada pokea asap dengan bahan pengasap cangkang kelapa sawit (A2) yaitu 38,13 sedangkan perlakuan dengan menggunakan cangkang kelapa sawit dan tempurung kelapa (A3) mendapatkan kadar protein paling rendahyaitu 27,07.Kadar protein dapat menurun karena adanya proses pengolahan, dengan terjadinya denaturasi protein selama pemanasan (Swastawatiet al, 2012). Penurunan kadar protein terjadi karena protein terurai oleh enzim proteolitik dan bantuan bakteri menjadi asam karboksilat (Zakaria, 1996).Menurut Isamu et al (2012) yang meneliti kandungan proksimat pada kadar protein ikan cakalang asap berbagai produsen yang terdapat di Kendari, yaitu nilai berkisar $31.13 \pm 0.44$.Hal tersebut didukung oleh pernyataan Swastawati et al. (2012) yang menyatakan bahwa kadar protein dapat menurun karena adanya proses pengolahan, dengan terjadinya denaturasi protein selama pemanasan.

\section{Serat Kasar}

Hasil nilai serat kasar padapokea asap berdasarkan berat kering dengan menggunakan bahan pengasap yang berbedamemberikan hasil yang berbeda, yaitu 3,$21 ; 7,34 ; 2,6$. untuk masingmasing pokea asap dengan bahan pengasap tempurung kelapa; cangkang kelapa sawit; tempurung kelapa dan cangkang kelapa sawit. Kadar serat tertinggiditemukan pada pokea asap dengan bahan cangkang kelapa sawit (A2) yaitu $7,34 \%$ sedangakan kadar seratterendah ditemukan pada pokea asap dengan bahan pengasap bahan bakar cangkang kelapa sawit dan tempurung kelapa (A3) yaitu 2,6\%. Bahan makanan yang mengandung banyak serat kasar lebih tinggi kecernaannya dibanding bahan makanan yang lebih banyak mengandung bahan ekstrak tanpa nitrogen (Arif, 2006).Penelitian serat kasar menurut (Idah dan Nwankwo, 2013) terhadap ikan nila asap perlakuan suhu dan waktu yang berbeda menghasilkan serat kasar yang tinggi adalah 1,30\%.Menurut Murniyati dan Sunarman (2000), kandungan karbohidrat (termasuk serat kasar) ikan, berkisar antara 1-2\%.

\section{Polycyclic Aromatic Hydrocarbon (PAH)}

Data hasil penelitian Polycylic Aromatic Hidrokarbon (PAH) pada pokea asap dengan bahan pengasap yang berbeda dapat dilihat padaTabel 3 . 
Tabel 3. Hasil analisa Polycylic Aromatic Hidrokarbon (PAH) pada pokea asap

\begin{tabular}{lllll}
\hline \multirow{2}{*}{ No } & \multirow{2}{*}{ Parameter Uji } & \multicolumn{3}{c}{ Bahan pengasap } \\
\cline { 3 - 5 } & & A1 & A2 & A3 \\
\hline 1 & Naphtalen & 4,29 & 0,98 & 0,60 \\
2 & Acenaphtalen & 17,19 & 2,22 & 4,10 \\
3 & Phenanthrene & 3,48 & 1,39 & 2,59 \\
4 & Pyrene & 1,43 & 2,01 & 3,63 \\
5 & Benzo(a)antracene & 4,52 & 2,43 & 3,51 \\
6 & Benzo(a)pyrene & 8,25 & 17,87 & 12,16 \\
\hline
\end{tabular}

Keterangan : $\mathrm{A} 1=$ Tempurung kelapa, $\mathrm{A} 2=$ Cangkang kelapa sawit, $\mathrm{A} 3=$ Tempurung kelapa dan cangkang kelapa sawit

Hasil kandungan benzo(a)pyrene paling banyak terdapat pada pokea asap dengan bahan pengasap cangkang kelapa sawit (A2) yaitu17,87, ppm sedangkan pada pokea asap dengan bahan pengasap tempurung kelapa (A1) dan pokea asap dengan bahan pengasap tempurung kelapa dan cangkang kelapa sawit (A3) berturut-turut $8,25 \mathrm{ppm}$ dan $12,16 \mathrm{ppm}$. Nilai tersebut berada diatas batas yang disyaratkan European Standard.Senyawa PAH (Polycyclic Aromatic Hydrocaron) yang diuji pada pokea asap antara lain naphthalene, acenaphtene, phenentrene, fluoranthene, pyrene, benzo(a)antracene, perylene dan benzo(a)pyren. Semua senyawa tersebut bersifat karsinogenik baik yang berbahaya kepada manusia dan yang tidak berbahaya.Tinggginya kandungan benzo(a)pyrene pada bahan bakar cangkang kelapa sawit (A2) diduga dipengaruhi oleh tingginya kadar lemak yang dimilikinya. Jumlah $P A H$ yang terbentuk selama pengolahan juga tergantung pada kandungan lemak. Lemak yang meleleh dan jatuh pada bahan bakar yang panas akan menyebabkan terjadinya pirolisis lemak yang dapat menghasilkan $P A H$ yang menguap dan tersimpan pada permukaan makanan (Menichini dan Bocca, 2003).
Kandungan benzo(a)pyrene dari ikan asap yang diolah dengan pengasapan panas berkisar antara 0,53,5 ppm, tergantung pada ukuran, preparasi dan kondisi pengasapan. Kandungan PAH dipengaruhi oleh proses pengolahan seperti suhu pembakaran kayu, waktu pengasapan, ketebalan asap, aliran udara, bahan baku dan kondisi pengasapan lainnya. Kandungan PAH akan meningkat seiring dengan meningkatnya suhu (Whittle dan Howgate, 2000).

\section{KESIMPULAN}

Berdasarkan uji sensorik pokea asap nilai aroma tertinggi yaitu 6,6 (A1) tempurung kelapa. Warna tertinggi yaitu 7,3 (A1) tempurung kelapa. Umami tertinggi yaitu 5,9 (A2) cangkang kelapa sawit. Saltiness tertinggi yaitu 5,6 (A1) tempurung kelapa. Tekstur tertinggi yaitu 5,2 (A1) tempurung kelapa dan (A2) cangkang kelapa sawit. Berdasarkan kandungan proksimat, kandungan kadar protein hasil tertinggi pada pokea asap dengan bahan pengasap cangkang kelapa sawit. Berdasarkan kandungan Polycyclic Aromatic Hidrocarbon kandungan (Benzo(a)phyrene) hasil terendah pada pokea asap dengan bahan pengasap tempurung kelapa. 


\section{DAFTAR PUSTAKA}

Adawyah R. 2007. Pengolahan dan Pengawetan Ikan. Bumi Aksara Jakarta.

Adawyah R. 2008. Pengolahan dan Pengawetan Ikan. PT Bumi Aksara. Jakarta.

Afrianto E, Liviawaty1. 989. Pengawetan dan Pengolahan Ikan. Yogyakarta: Penerbit Kanisius.

Agus TSW, Swastawati F, Anggo AP. 2014. Kualitas Ikan Pari (Dasyatis sp) Asap Yang Diolah Dengan Ketinggian Tunggu Dan Suhu Yang Berbeda. Jurnal Pengolahan dan Bioteknologi Hasil Perikanan.3(1): 147-156.

AOAC. 1970. Methods of Analysis. Association og Official Agriculturan Chemists. Whasingthon D.C.

Arif IS, Skizofrenia. 2006. Bandung: PT. Refika Aditama.

Bahtiar. 2005. Kajian Populasi Pokea (B.violacea celebensisMartens 1987) di sungai Pohara Kendari Selawesi Tenggara. [Tesis]. IPB. Bogor.

Bahtiar. 2007. Kepadatan dan Dostribusi Pokea (B.violacea celebensis Martens 1987) Pada Substrat Yang Berbeda di Sungai Pohara Sulawesi Tenggara.

Buckle KA. 1985. Ilmu Pangan, Penerbit Universitas Indonesia, Jakarta

Erdiansyah, 2006. Teknologi Penanganan Bahan Baku Terhadap Mutu Sosis Ikan Patin (Pangasius Pangasius) [tesis].
Bogor: Sekolah Pasca Serjana. IPB. Bogor

Fountaine, Pascal. 2006. Europe in 12 Lessons. Brussels: Directorate General for Communication Publications European Commission.

Giullen MD, Manzanos MJ. 2002. Study of the volatile composition of an aqueous oak smoke preparation. Food Chemistry. 79:283-292

Harikedua JW. 2002. Metode Analisis Kimia Hasil Perikanan. Penuntun Praktikum. Fakultas Perikanan. UNSRAT. Manado.

Idah, P.A., and Nwankwo, I. (2013). Effects of smoke-drying temperatures and time on physical and nutritional quality parameters of tilapia (oreochromis niloticus). J. Fisheries and Aquaculture. vol. 5 (3). Pp. 29-34.

Isamu KT, Purnomo H, Yuwono SS. 2012. Karakteristik Fisik, Kimia, dan Organoleptik Ikan Cakalang (Katsuwonus pelamis) Asap di Kendari. Jurnal Teknologi Pertania. 13:105-110.

Laksmi. 2012. Interaksi, Interpretasi dan Makna. Bandung: Karya Putra Darwati.

Martinez O, Salmeron J, Guillen MD, Casas C. 2007. Sensorial and physicochemical caharacteristics of salmon (Salmo salar) treated by different smoking process during storage. Food Science and Technology International. 13(6): 477-484.

Menichini E, Bocca B. 2003. Polycyclic Aromatic Hydrocarbons. Di dalam: Caballero B, Trugo L, Finglas PM, editor. 
Encyclopedia of Food Sciences and Nutrition. Maryland: Academic Press. hlm 46164625 .

Mueljanto. 1992. Pengawetan dan Pengolahan Hasil Perikanan. Jakarta: Penebar Swadaya

Murniyati AS. dan Sunarman. 2000. Pendinginan, Pembekuan dan Pengawetan Ikan. PT. Kanisius. Jakarta.

Rahayu SM. 2012. Pengaruh konsentrasi Garam Dalam Proses Perebusan Ikan Teri (stolephorus sp.) Setengah Kering dan Pendugaan Umur Simpannya Dengan Metode Akselerasi. FPIK IPB. Bogor.

Saleh M, Sari A 2007. Kumpulan hasilhasil Penelitian Pascapenen Perikanan. Balai besar Riset Pengolahan Produk dan Bioteknologi Kelautan dan Perikanan. Jakarta. 313 Hal.

Simko P. 2005. Factors affecting elimination of polycyclic aromatic hydrocarbons from smoked meat foods and liquid smoke flavourings: a review of molecular nutrition. Food Research. 49: 637-647

Sudarrmadji S, Haryono B, Suhadi. 2007. Analisa Bahan Makanan dan Pertanian. Liberty. Yogyakarta.

Swastawati F, Eko S, Bambang C, Wahyu AJ. 2012. Sensory Evaluation and Chemical Charesteric of Smoked Stingray (Dasyatis bleekery) Processed by Using Two Different Liquid Smoke. International Journal of Bioscience, Biochemistry and Biofarmatics. 2(3): 212-216
Swastawati F, Titi SU, Tri WA, Putut HR. 2013. Karakteristik kualitas ikan asap yang diproses menggunakan metode dan jenis ikan berbeda. Jurnal Aplikasi Teknologi Pangan. 2(3): 126132.

Tejasari. 2005. Nilai-Nilai Gizi Pangan. Graha ilmu. Jakarta

Whittle KJ, Howgate P. 2002. Glossary of Fish Technology Terms. Prepared under contract to the Fisheries Industries Division of the Food and Agriculture Organization of the United Nations.

Wibowo S. 2000. Industri Pengasapan Ikan. Penebar Swadaya. Yogyakarta.

Winarno FG. 2002. Kimia Pangan dan Gizi. Gramedia Pustaka Utama. Jakarta

Zakaria F. 1996. Toksisitas dan imunogenitas pigmen angkak yang diproduksi dari kapang Monascus purpureus pada substrat limbah cair tapioka. Buletin Teknologi dan Industri Pangan. 1(12): 34-38. 